Supporting Information

Color-Tunable Long-Lived Room-Temperature

Phosphorescence in a Coordination Polymer Based on a

Nonaromatic Ligand and Its Phosphor/Coordination Polymer

Doped Systems

Yu-Jie Yin, He Zhao, Lingwen Zhang, Jiaxiang Huang, Jian-Jun Zhang, * Jun Chen, Jun Ni, Bo Song, * Shuqin Liu, and Chunying Duan* 


\section{Supporting Tables}

Table S1. Crystallographic data for complex 1.

\begin{tabular}{ll}
\hline & $\mathbf{1}$ \\
\hline Formula & $\mathrm{C}_{24} \mathrm{H}_{42} \mathrm{Ca}_{5} \mathrm{O}_{22} \mathrm{~S}_{2}$ \\
Formula weight & 947.09 \\
Crystal system & monoclinic \\
Space group & $\mathrm{P} 2(1) / \mathrm{c}$ \\
$a(\AA)$ & $10.3586(3)$ \\
$b(\AA)$ & $12.4740(4)$ \\
$c(\AA)$ & $16.2912(5)$ \\
$\alpha\left(^{\circ}\right)$ & 90 \\
$\beta\left(^{\circ}\right)$ & $93.407(1)$ \\
$\gamma\left({ }^{\circ}\right)$ & 90 \\
$V\left(\AA^{3}\right) / Z$ & $2101.32(11) / 2$ \\
$D$ calcd $\left(\mathrm{g} / \mathrm{cm}{ }^{3}\right)$ & 1.497 \\
$\mu\left(\mathrm{mm}^{-1}\right)$ & 0.812 \\
$F(000)$ & 988 \\
$\theta$ range $\left.{ }^{\circ}\right)$ & $3.278 \sim 25.000$ \\
Reflections collected / unique & $31726 / 3681$ \\
$R($ int $)$ & 0.0242 \\
$\mathrm{GOF}$ on F & 1.039 \\
$R I^{\mathrm{a}}, I>2 \sigma(I)($ all $)$ & $0.0419(0.0486)$ \\
$w R 2^{\mathrm{b}}, I>2 \sigma(I)($ all $)$ & $0.1183(0.1229)$ \\
Max/mean shift in final cycle $)$ & $0.001 / 0.000$ \\
\hline
\end{tabular}

${ }^{a} R=\sum\left(|| \mathrm{F}_{\mathrm{o}}|-| \mathrm{F}_{\mathrm{c}} \mid\right) / \sum\left|\mathrm{F}_{\mathrm{o}}\right|, \quad{ }^{\mathrm{b}} R w=\left\{\sum \mathrm{w}\left[\left(\mathrm{F}^{2}{ }_{\mathrm{o}}-\mathrm{F}^{2} \mathrm{c}\right)\right] / \sum \mathrm{w}\left[\left(\mathrm{F}^{2}\right)^{2}\right]\right\}^{0.5}, \mathrm{w}=\left[\sigma^{2}\left(\mathrm{~F}^{2}{ }_{\mathrm{o}}\right)+(\mathrm{aP})^{2}+\mathrm{bP}\right]^{-1}$, where $\mathrm{P}=$ $\left(\mathrm{F}_{\mathrm{o}}^{2}+2 \mathrm{~F}_{\mathrm{c}}^{2}\right) / 3$. ]. $1, a=0.0713, b=2.8083$.

Table S2. Bond lengths $(\AA)$ and angles $\left(^{\circ}\right)$ for $\mathbf{1}$.

\begin{tabular}{ll|ll}
\hline $\mathrm{Ca}(1)-\mathrm{O}(3)$ & $2.3474(19)$ & $\mathrm{Ca}(1)-\mathrm{O}(6)$ & $2.362(2)$ \\
$\mathrm{Ca}(1)-\mathrm{O}(9) \# 1$ & $2.3571(19)$ & $\mathrm{Ca}(1)-\mathrm{O}(9)$ & $2.3571(19)$ \\
$\mathrm{Ca}(2)-\mathrm{O}(8) \# 2$ & $2.318(2)$ & $\mathrm{Ca}(3)-\mathrm{O}(2)$ & $2.337(2)$ \\
$\mathrm{Ca}(2)-\mathrm{O}(1)$ & $2.335(2)$ & $\mathrm{Ca}(3)-\mathrm{O}(11)$ & $2.337(3)$ \\
$\mathrm{Ca}(2)-\mathrm{O}(10) \# 2$ & $2.378(2)$ & $\mathrm{Ca}(3)-\mathrm{O}(4) \# 3$ & $2.3676(19)$ \\
$\mathrm{Ca}(2)-\mathrm{O}(7)$ & $2.3819(19)$ & $\mathrm{Ca}(3)-\mathrm{O}(5)$ & $2.394(2)$ \\
$\mathrm{Ca}(2)-\mathrm{O}(5)$ & $2.393(2)$ & $\mathrm{Ca}(3)-\mathrm{O}(7)$ & $2.405(2)$ \\
$\mathrm{Ca}(2)-\mathrm{O}(4)$ & $2.521(2)$ & $\mathrm{Ca}(3)-\mathrm{O}(10)$ & $2.519(2)$ \\
$\mathrm{Ca}(2)-\mathrm{O}(3)$ & $2.552(2)$ & $\mathrm{Ca}(3)-\mathrm{O}(9)$ & $2.526(2)$ \\
& & & \\
$\mathrm{O}(3) \# 1-\mathrm{Ca}(1)-\mathrm{O}(3)$ & 180 & $\mathrm{O}(8) \# 2-\mathrm{Ca}(2)-\mathrm{O}(1)$ & $95.61(9)$ \\
$\mathrm{O}(3) \# 1-\mathrm{Ca}(1)-\mathrm{O}(9)$ & $87.14(7)$ & $\mathrm{O}(8) \# 2-\mathrm{Ca}(2)-\mathrm{O}(10) \# 2$ & $85.61(8)$
\end{tabular}




\begin{tabular}{ll|ll}
$\mathrm{O}(3)-\mathrm{Ca}(1)-\mathrm{O}(9)$ & $92.86(7)$ & $\mathrm{O}(1)-\mathrm{Ca}(2)-\mathrm{O}(10) \# 2$ & $84.29(8)$ \\
$\mathrm{O}(3) \# 1-\mathrm{Ca}(1)-\mathrm{O}(9) \# 1$ & $92.85(7)$ & $\mathrm{O}(8) \# 2-\mathrm{Ca}(2)-\mathrm{O}(7)$ & $169.16(8)$ \\
$\mathrm{O}(3)-\mathrm{Ca}(1)-\mathrm{O}(9) \# 1$ & $87.15(7)$ & $\mathrm{O}(1)-\mathrm{Ca}(2)-\mathrm{O}(7)$ & $85.73(9)$ \\
$\mathrm{O}(9)-\mathrm{Ca}(1)-\mathrm{O}(9) \# 1$ & 180 & $\mathrm{O}(10) \# 2-\mathrm{Ca}(2)-\mathrm{O}(7)$ & $105.23(7)$ \\
$\mathrm{O}(3) \# 1-\mathrm{Ca}(1)-\mathrm{O}(6)$ & $89.49(8)$ & $\mathrm{O}(8) \# 2-\mathrm{Ca}(2)-\mathrm{O}(5)$ & $90.85(8)$ \\
$\mathrm{O}(3)-\mathrm{Ca}(1)-\mathrm{O}(6)$ & $90.51(8)$ & $\mathrm{O}(1)-\mathrm{Ca}(2)-\mathrm{O}(5)$ & $84.62(9)$ \\
$\mathrm{O}(9)-\mathrm{Ca}(1)-\mathrm{O}(6)$ & $90.64(8)$ & $\mathrm{O}(10) \# 2-\mathrm{Ca}(2)-\mathrm{O}(5)$ & $167.97(8)$ \\
$\mathrm{O}(9) \# 1-\mathrm{Ca}(1)-\mathrm{O}(6)$ & $89.36(8)$ & $\mathrm{O}(7)-\mathrm{Ca}(2)-\mathrm{O}(5)$ & $78.54(7)$ \\
$\mathrm{O}(3) \# 1-\mathrm{Ca}(1)-\mathrm{O}(6) \# 1$ & $90.51(8)$ & $\mathrm{O}(8) \# 2-\mathrm{Ca}(2)-\mathrm{O}(4)$ & $84.58(8)$ \\
$\mathrm{O}(3)-\mathrm{Ca}(1)-\mathrm{O}(6) \# 1$ & $89.49(8)$ & $\mathrm{O}(1)-\mathrm{Ca}(2)-\mathrm{O}(4)$ & $152.73(8)$ \\
$\mathrm{O}(9)-\mathrm{Ca}(1)-\mathrm{O}(6) \# 1$ & $89.37(8)$ & $\mathrm{O}(10) \# 2-\mathrm{Ca}(2)-\mathrm{O}(4)$ & $68.51(7)$ \\
$\mathrm{O}(9) \# 1-\mathrm{Ca}(1)-\mathrm{O}(6) \# 1$ & $90.63(8)$ & $\mathrm{O}(7)-\mathrm{Ca}(2)-\mathrm{O}(4)$ & $99.16(7)$ \\
$\mathrm{O}(6)-\mathrm{Ca}(1)-\mathrm{O}(6) \# 1$ & 180 & $\mathrm{O}(5)-\mathrm{Ca}(2)-\mathrm{O}(4)$ & $122.65(7)$ \\
$\mathrm{O}(2)-\mathrm{Ca}(3)-\mathrm{O}(11)$ & $91.11(11)$ & $\mathrm{O}(8) \# 2-\mathrm{Ca}(2)-\mathrm{O}(3)$ & $93.08(8)$ \\
$\mathrm{O}(2)-\mathrm{Ca}(3)-\mathrm{O}(4) \# 3$ & $80.94(8)$ & $\mathrm{O}(1)-\mathrm{Ca}(2)-\mathrm{O}(3)$ & $155.58(8)$ \\
$\mathrm{O}(11)-\mathrm{Ca}(3)-\mathrm{O}(4) \# 3$ & $98.61(9)$ & $\mathrm{O}(10) \# 2-\mathrm{Ca}(2)-\mathrm{O}(3)$ & $119.17(7)$ \\
$\mathrm{O}(2)-\mathrm{Ca}(3)-\mathrm{O}(5)$ & $82.78(9)$ & $\mathrm{O}(7)-\mathrm{Ca}(2)-\mathrm{O}(3)$ & $81.65(7)$ \\
$\mathrm{O}(11)-\mathrm{Ca}(3)-\mathrm{O}(5)$ & $87.88(9)$ & $\mathrm{O}(5)-\mathrm{Ca}(2)-\mathrm{O}(3)$ & $72.46(7)$ \\
$\mathrm{O}(4) \# 3-\mathrm{Ca}(3)-\mathrm{O}(5)$ & $162.56(8)$ & $\mathrm{O}(4)-\mathrm{Ca}(2)-\mathrm{O}(3)$ & $50.90(6)$ \\
$\mathrm{O}(2)-\mathrm{Ca}(3)-\mathrm{O}(7)$ & $86.59(9)$ & $\mathrm{O}(4) \# 3-\mathrm{Ca}(3)-\mathrm{O}(9)$ & $119.66(7)$ \\
$\mathrm{O}(11)-\mathrm{Ca}(3)-\mathrm{O}(7)$ & $165.94(9)$ & $\mathrm{O}(5)-\mathrm{Ca}(3)-\mathrm{O}(9)$ & $76.22(7)$ \\
$\mathrm{O}(4) \# 3-\mathrm{Ca}(3)-\mathrm{O}(7)$ & $94.73(7)$ & $\mathrm{O}(7)-\mathrm{Ca}(3)-\mathrm{O}(9)$ & $87.09(7)$ \\
$\mathrm{O}(5)-\mathrm{Ca}(3)-\mathrm{O}(7)$ & $78.07(7)$ & $\mathrm{O}(10)-\mathrm{Ca}(3)-\mathrm{O}(9)$ & $51.29(6)$ \\
$\mathrm{O}(2)-\mathrm{Ca}(3)-\mathrm{O}(10)$ & $149.61(8)$ & $\mathrm{O}(11)-\mathrm{Ca}(3)-\mathrm{O}(9)$ & $90.15(9)$ \\
$\mathrm{O}(11)-\mathrm{Ca}(3)-\mathrm{O}(10)$ & $92.38(9)$ & $\mathrm{Ca}(1)-\mathrm{O}(3)-\mathrm{Ca}(2)$ & $125.55(8)$ \\
$\mathrm{O}(4) \# 3-\mathrm{Ca}(3)-\mathrm{O}(10)$ & $68.69(7)$ & $\mathrm{Ca}(3) \# 2-\mathrm{O}(4)-\mathrm{Ca}(2)$ & $101.48(7)$ \\
$\mathrm{O}(5)-\mathrm{Ca}(3)-\mathrm{O}(10)$ & $127.50(7)$ & $\mathrm{Ca}(2)-\mathrm{O}(5)-\mathrm{Ca}(3)$ & $99.03(8)$ \\
$\mathrm{O}(7)-\mathrm{Ca}(3)-\mathrm{O}(10)$ & $96.61(7)$ & $\mathrm{Ca}(2)-\mathrm{O}(7)-\mathrm{Ca}(3)$ & $99.05(7)$ \\
$\mathrm{O}(2)-\mathrm{Ca}(3)-\mathrm{O}(9)$ & $158.90(8)$ & $\mathrm{Ca}(2) \# 3-\mathrm{O}(10)-\mathrm{Ca}(3)$ & $101.22(7)$ \\
\hline & & &
\end{tabular}

Symmetry transformations used to generate equivalent atoms:

$\# 1:-x+1,-y+1,-z ; \# 2:-x+1, y+1 / 2,-z+1 / 2 ; \# 3:-x+1, y-1 / 2,-z+1 / 2$. 
Table S3. The luminescence lifetimes of $\mathbf{1}$ and its composities.

\begin{tabular}{cccccccc}
\hline Samples & Excitation $(\mathrm{nm})$ & Emission $(\mathrm{nm})$ & $\tau_{1}(\mathrm{~ms})$ & $\mathrm{A} 1(\%)$ & $\tau_{2}(\mathrm{~ms})$ & $\mathrm{A} 2(\%)$ & $\tau_{\mathrm{av}}(\mathrm{ms})$ \\
\hline $\mathbf{1}$ & 258 & 483 & 720 & 71.66 & 66 & 28.34 & 534.64 \\
\hline $\mathbf{1 A}$ & 258 & 479 & 530 & 94.65 & 100 & 5.35 & 506.98 \\
\hline PABA & 258 & 430 & 0.12 & 93.52 & 0.014 & 6.48 & 0.1131 \\
\hline PABA/1 & 258 & 428 & 1000 & 82.32 & 320 & 17.68 & 879.75 \\
\hline PPTA/1 & 254 & 420 & 690 & 89.35 & 100 & 10.66 & 627.14 \\
\hline PHBA/1 & 279 & 425 & 540 & 71.51 & 110 & 28.49 & 417.49 \\
\hline NAI1/1 & 258 & 456 & 200 & 65.37 & 42 & 34.63 & 145.29 \\
\hline NAI1/1 & 258 & 483 & 460 & 8184 & 67 & 18.16 & 388.62 \\
\hline NAI1/1 & 258 & 550 & 250 & 65.58 & 84 & 34.42 & 192.86 \\
\hline NAI1/1 & 258 & 592 & 210 & 80.52 & 70 & 19.48 & 182.73 \\
\hline NAI2/1 & 279 & 465 & 340 & 65.40 & 49 & 34.60 & 239.31 \\
\hline NAI2/1 & 279 & 505 & 380 & 70.03 & 50 & 29.97 & 281.10 \\
\hline NAI2/1 & 279 & 540 & 420 & 71.41 & 56 & 28.59 & 314.44 \\
\hline NAI3/1 & 254 & 465 & 410 & 50.64 & 73 & 49.36 & 243.65 \\
\hline NAI3/1 & 254 & 555 & 260 & 91.81 & 48 & 8.19 & 241.50 \\
\hline NAI3/1 & 254 & 595 & 270 & 87.08 & 73 & 12.92 & 244.54 \\
\hline
\end{tabular}

Table S4. The luminescence lifetimes of PABA/1 composities with different concentrations of PABA guest.

\begin{tabular}{ccccccccc}
\hline $\begin{array}{c}\mathrm{Ca}^{2+}: \text { PABA } \\
\begin{array}{c}\text { Initial molar } \\
\text { ratio })\end{array}\end{array}$ & $\begin{array}{c}\mathrm{Ca}^{2+}: \text { PABA } \\
\text { (molar ratio in } \\
\text { products })\end{array}$ & $\begin{array}{c}\text { Excitation } \\
(\mathrm{nm})\end{array}$ & $\begin{array}{c}\text { Emission } \\
(\mathrm{nm})\end{array}$ & $\tau_{1}(\mathrm{~ms})$ & $\mathrm{A} 1(\%)$ & $\tau_{2}(\mathrm{~ms})$ & $\mathrm{A} 2(\%)$ & $\tau_{\mathrm{av}}(\mathrm{ms})$ \\
\hline $10000: 1$ & $6.7 \times 10^{-6}: 1$ & 258 & 425 & 360 & 90.34 & 82 & 9.66 & 333.15 \\
\hline $10000: 1$ & $6.7 \times 10^{-6}: 1$ & 258 & 483 & 510 & 92.95 & 62 & 7.05 & 478.48 \\
\hline $1000: 1$ & $7.8 \times 10^{-5}: 1$ & 258 & 425 & 830 & 83.85 & 110 & 16.15 & 713.72 \\
\hline $1000: 1$ & $7.8 \times 10^{-5}: 1$ & 258 & 483 & 400 & 85.30 & 87 & 14.70 & 354.00 \\
\hline $100: 1$ & $5.4 \times 10^{-4}: 1$ & 258 & 428 & 1000 & 82.32 & 320 & 17.68 & 879.75 \\
\hline $100: 1$ & $5.4 \times 10^{-4}: 1$ & 258 & 483 & 300 & 82.23 & 120 & 17.77 & 268.01 \\
\hline $50: 1$ & $2.37 \times 10^{-3}: 1$ & 258 & 428 & 910 & 82.35 & 140 & 17.65 & 774.09 \\
\hline $50: 1$ & $2.37 \times 10^{-3}: 1$ & 258 & 483 & 330 & 76.81 & 130 & 23.19 & 283.63 \\
\hline
\end{tabular}


Supporting Figures.

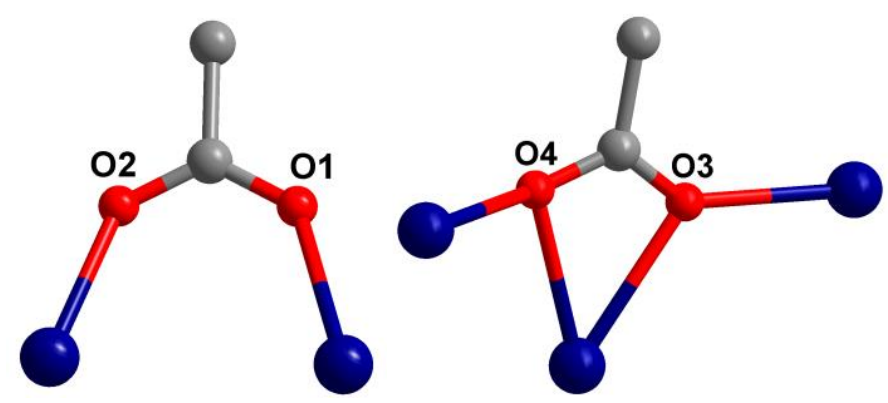

(a)

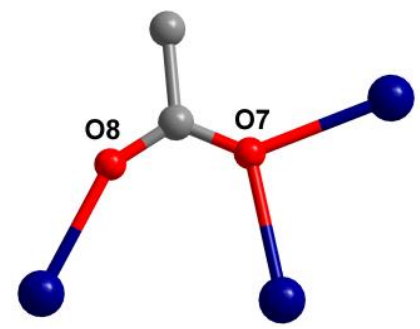

(d)

(b)

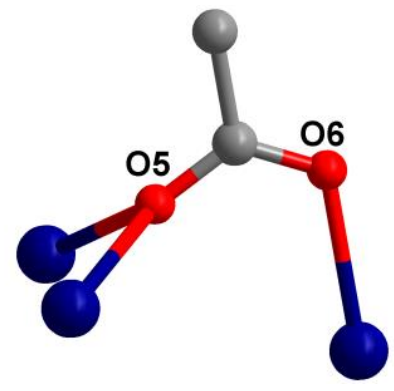

(c)

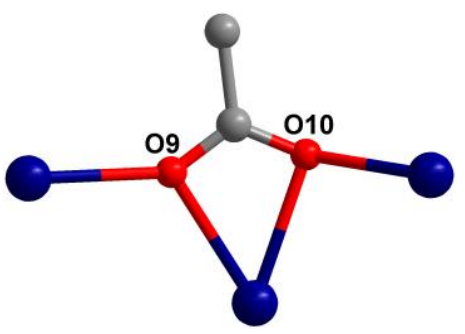

(e)

Figure S1. The coordinated modes of the acetate ligands in $\mathbf{1 .}$

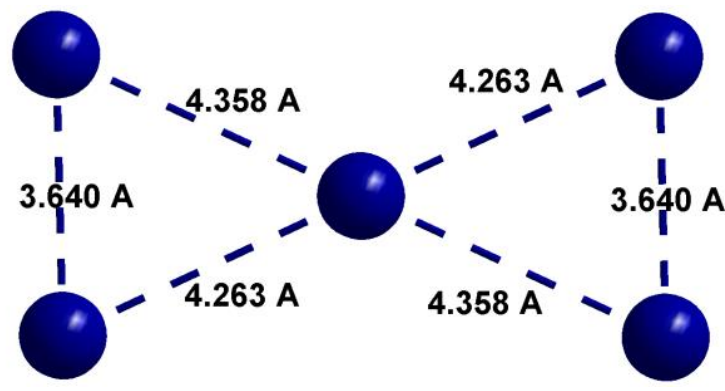

Figure S2. Metal skeleton of the $\left\{\mathrm{Ca} 5(\mathrm{Ac})_{10}\right\}$ building unit.

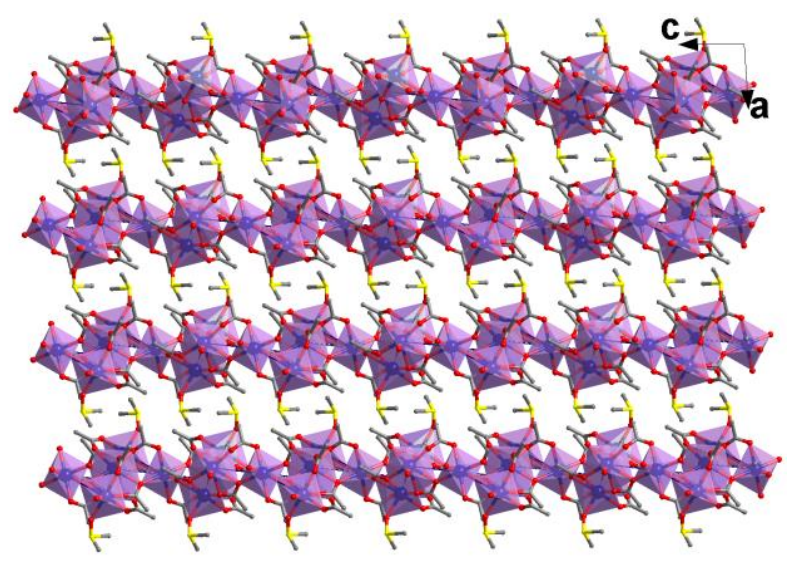


Figure S3. The packing of the 2D net viewed along the $b$ direction.

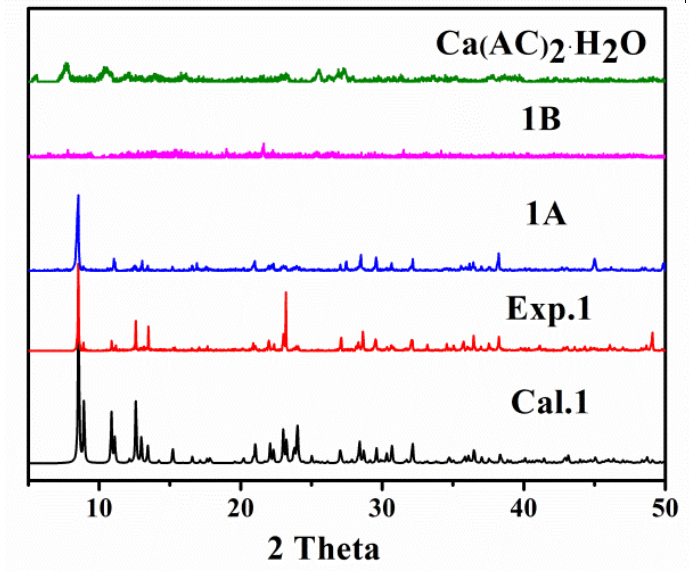

(a)

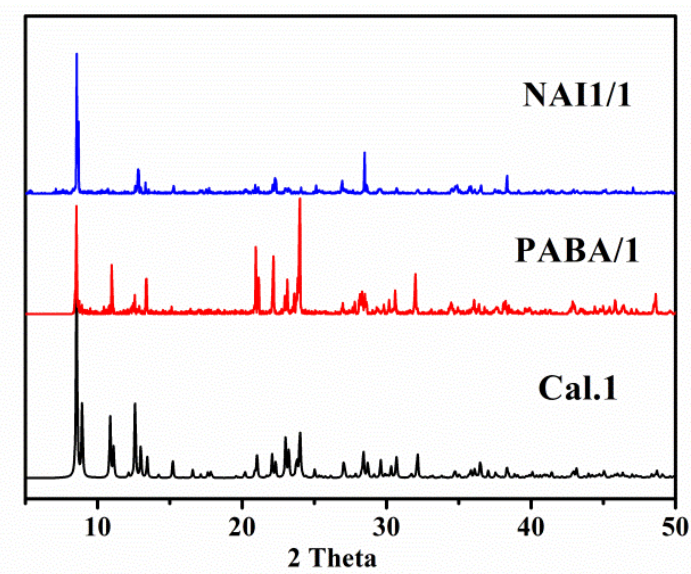

(b)

Figure S4. (a) A comparison of the calculated and experimental PXRD patterns of 1, patterns of 1 heated at $160{ }^{\circ} \mathrm{C}$ for $15 \min (\mathbf{1 A}), 1$ heated at $245{ }^{\circ} \mathrm{C}$ for $10 \mathrm{~min}(\mathbf{1 B})$ and the starting material $\mathrm{Ca}(\mathrm{AC})_{2} \cdot \mathrm{H}_{2} \mathrm{O}$. (b) A comparison of the PXRD patterns of $\mathbf{1}, \mathrm{PAPB} / \mathbf{1}$ and NAI1/1.

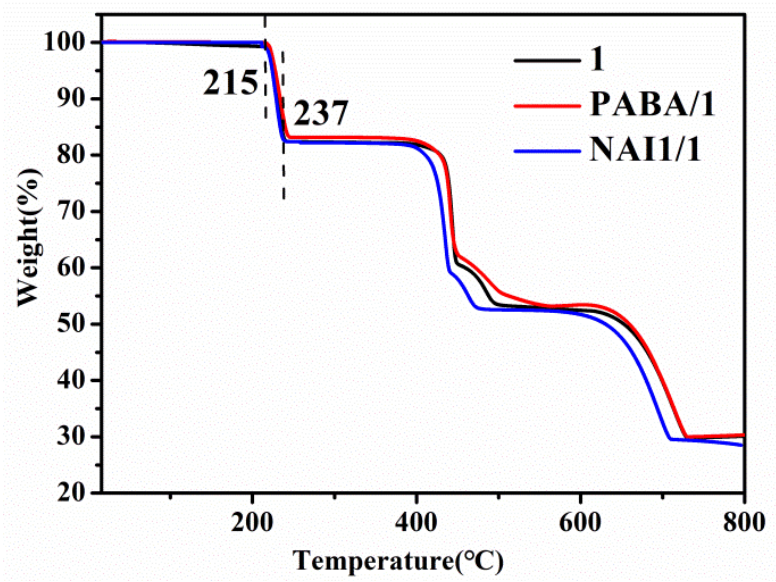

Figure S5. TGA curves of 1, PAPB/1 and NAI1/1.

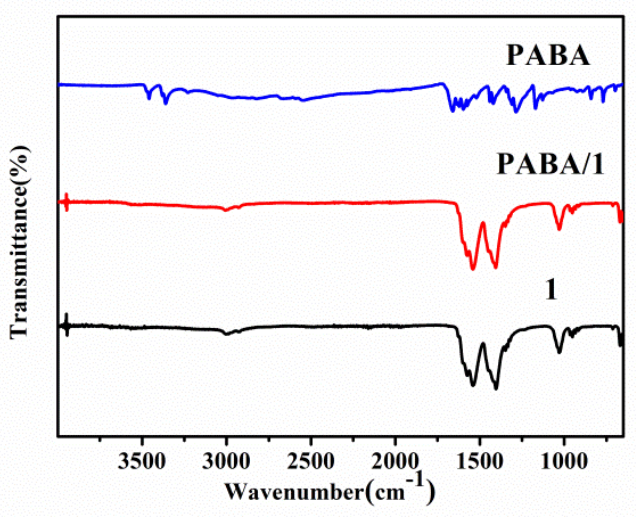

(a)

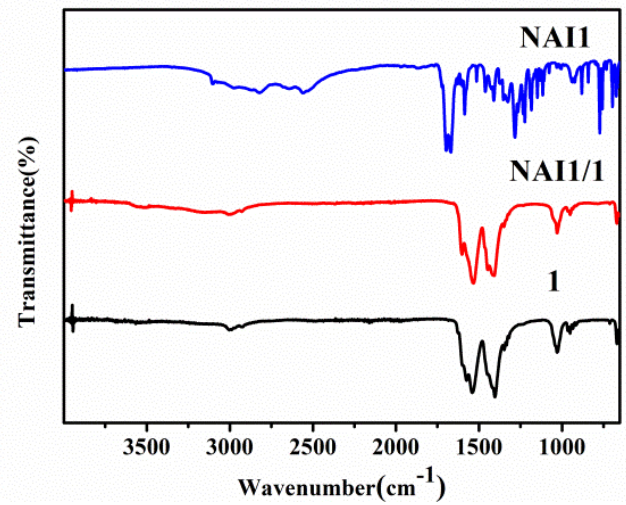

(b) 
Figure S6. (a) IR spectra of 1, PABA/1 and PABA. (b) IR spectra of 1, NAI1/1 and NAI1.

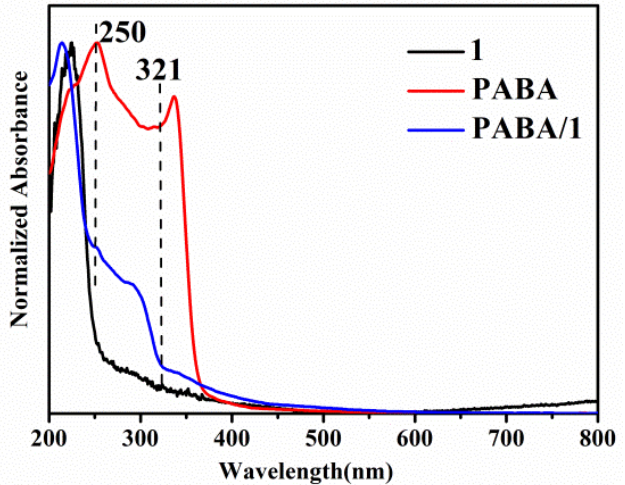

(a)

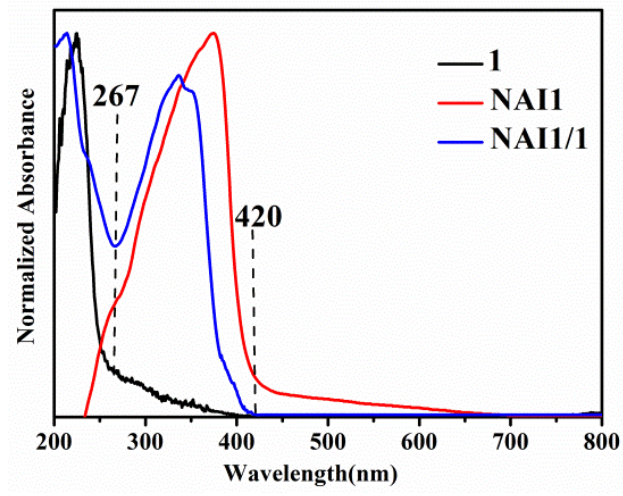

(b)

Figure S7. (a) A comparison of solid state UV-vis absorption spectra of 1, PABA and PABA/1.

(b) A comparison of solid state UV-vis absorption spectra of 1, NAI1/1 and NAI1.

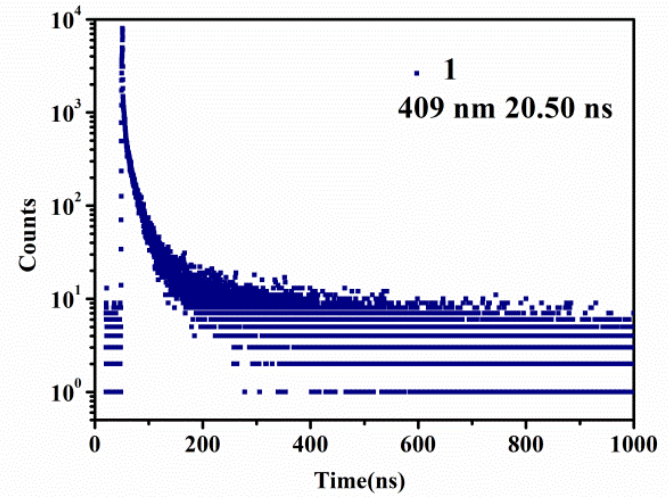

(a)

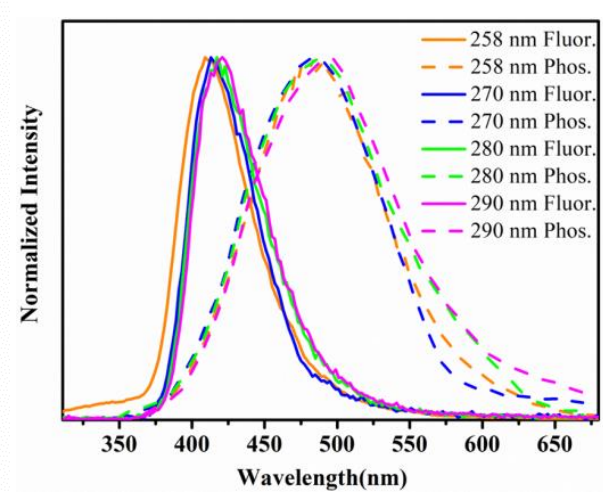

(b)

Figure S8. (a) Fluorescence decay curve of $\mathbf{1}$ monitored at 409 nm. (b) The solid state emission spectra of 1 under different excitation wavelengths. Fluorescence spectra (solid line; slit width, 2.5 $\mathrm{nm}$; voltage, $600 \mathrm{~V}$ ) and RTP spectra (dashed line; slit width, $20 \mathrm{~nm}$; voltage, $600 \mathrm{~V}$ ).

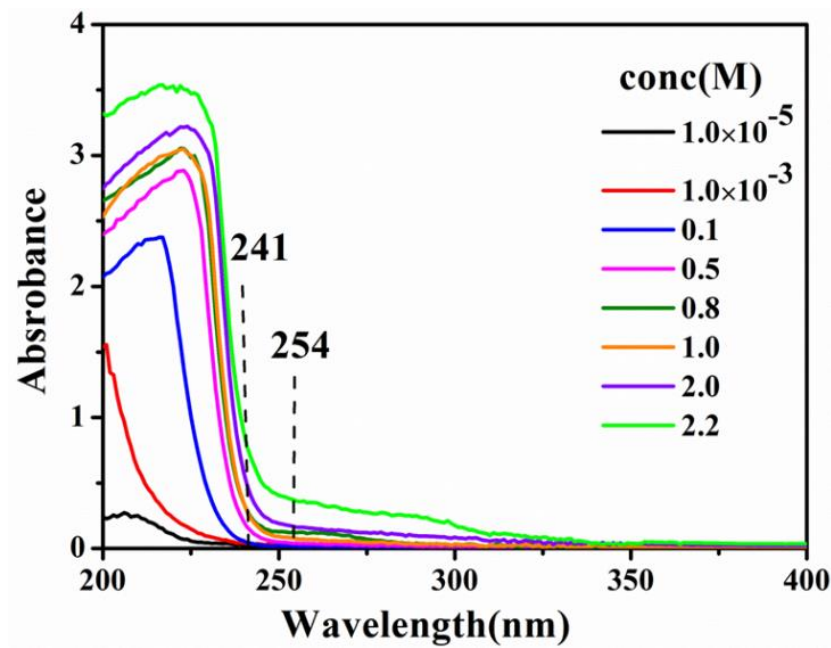


Figure S9. UV-vis spectra of $\mathrm{Ca}(\mathrm{AC})_{2}$ in $\mathrm{H}_{2} \mathrm{O}$ with different concentrations.

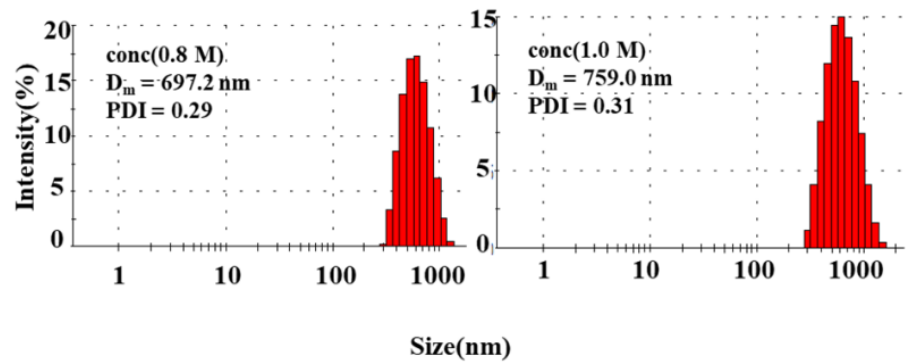

Figure S10. DLS data of $\mathrm{Ca}(\mathrm{AC})_{2}$ in $\mathrm{H}_{2} \mathrm{O}$ with different concentrations. Dm = mean diameter; PDI = polydispersity index

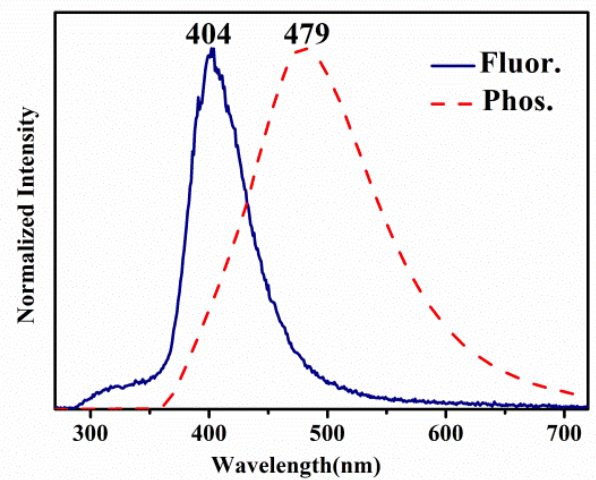

(a)

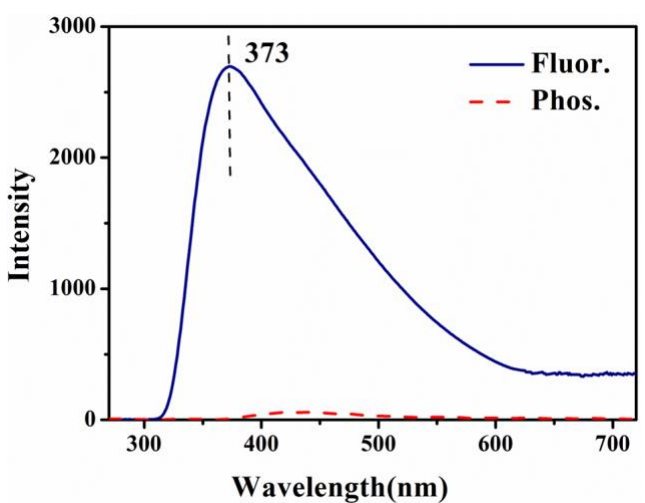

(b)

Figure S11. The solid-state PL spectra of the samples of $\mathbf{1}$ after being heated at $160{ }^{\circ} \mathrm{C}$ for 15 min (a) and $245{ }^{\circ} \mathrm{C}$ for $10 \mathrm{~min}$ (b) respectively. Fluorescence spectra (blue solid line; excitation, 258 nm; slit width, $5 \mathrm{~nm}$; voltage, $700 \mathrm{~V}$ ) and RTP spectra (red dashed line; excitation, $258 \mathrm{~nm}$; slit width, $20 \mathrm{~nm}$; voltage, $700 \mathrm{~V})$.

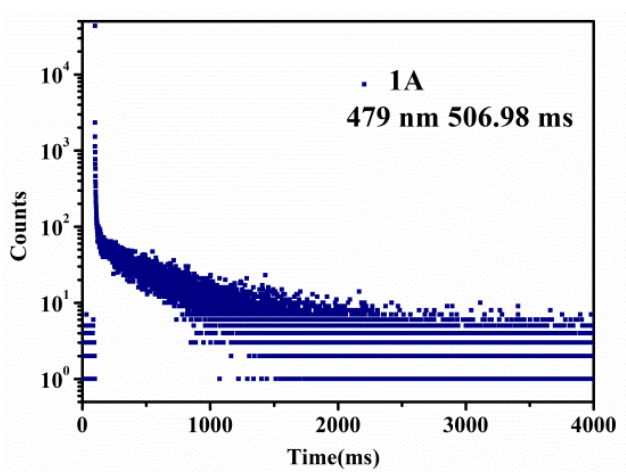

(a)

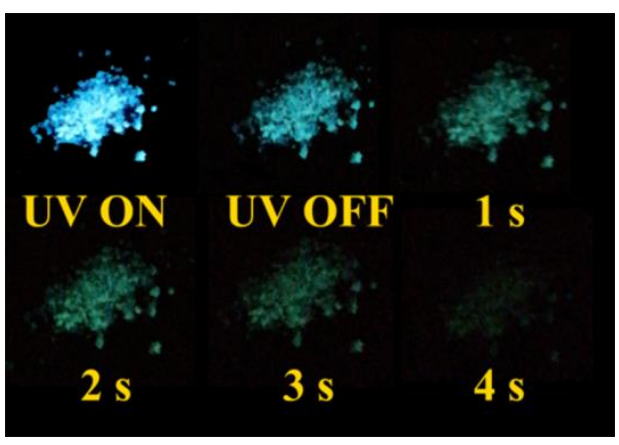

(b) 


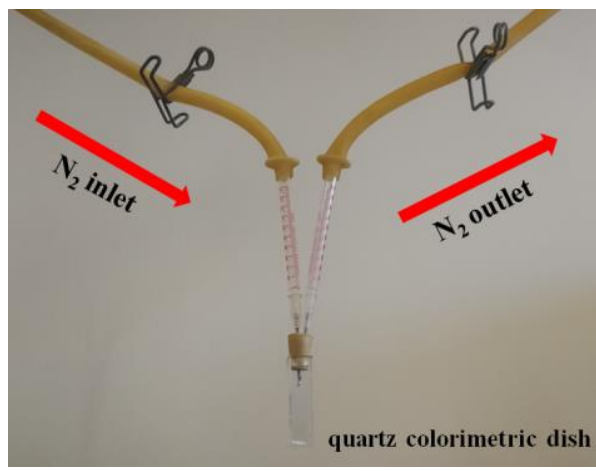

(c)

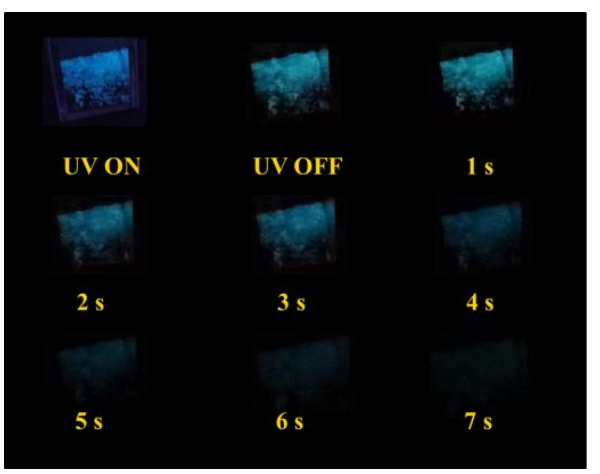

(d)

Figure S12. (a) Time-resolved phosphorescence decay curve of $479 \mathrm{~nm}$ emission of $\mathbf{1}$ after being heated at $160{ }^{\circ} \mathrm{C}$ for $15 \mathrm{~min}$. (b) Luminescence photographs of $\mathbf{1}$ after being heated at $160{ }^{\circ} \mathrm{C}$ for 15 min under irradiation and upon removal of a UV lamp $\left(\lambda_{\mathrm{ex}}=254 \mathrm{~nm}\right)$. (c) A simple device for studying the effect of air on the RTP of a sample. (d) Luminescence photographs of $\mathbf{1}$ under irradiation and upon removal of a UV lamp ( $\lambda_{\mathrm{ex}}=254 \mathrm{~nm}$, in nitrogen atmosphere).

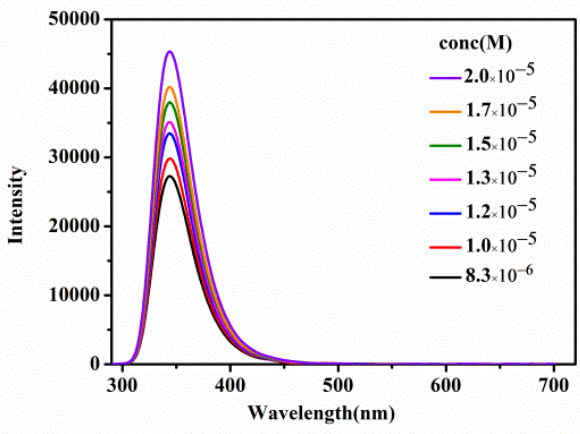

(a)

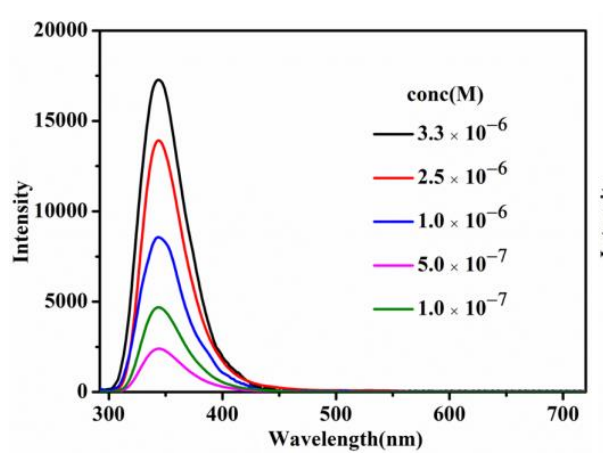

(c)

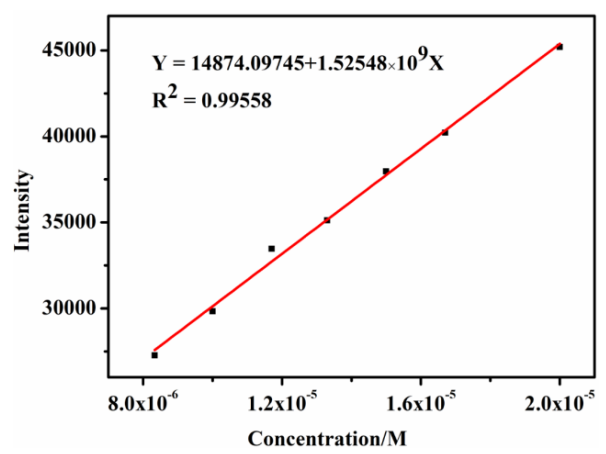

(b)

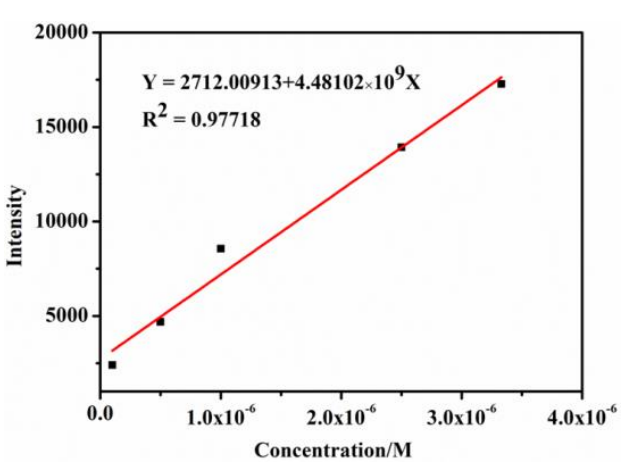

(d)

Figure S13. (a) Luminescent spectra of $\mathrm{H}_{2} \mathrm{O}$ solution of PABA at different concentrations $\left(8.3 \times 10^{-6} \sim 2.0 \times 10^{-5} \mathrm{M}\right)$ at room temperature. Excitation, $276 \mathrm{~nm}$; slit width, $10 \mathrm{~nm}$; voltage, $600 \mathrm{~V}$

(b) The luminescence intensity-concentration relationship for PABA $\left(8.3 \times 10^{-6} \sim 2.0 \times 10^{-5} \mathrm{M}\right)$ in $\mathrm{H}_{2} \mathrm{O}$ solution. (c) Luminescent spectra of $\mathrm{H}_{2} \mathrm{O}$ solution of PABA at different concentrations 
$\left(1.0 \times 10^{-7} \sim 3.3 \times 10^{-6} \mathrm{M}\right)$ at room temperature. Excitation, $276 \mathrm{~nm}$; slit width, $20 \mathrm{~nm}$; voltage, $600 \mathrm{~V}$.

(d) The luminescence intensity-concentration relationship for PABA $\left(1.0 \times 10^{-7} \sim 3.3 \times 10^{-6} \mathrm{M}\right)$ in $\mathrm{H}_{2} \mathrm{O}$ solution. Excitation, $276 \mathrm{~nm}$; slit width, $20 \mathrm{~nm}$; voltage, $600 \mathrm{~V}$.<smiles>Nc1ccc(C(=O)O)cc1</smiles><smiles>O=C(O)c1ccc(O)cc1</smiles>

PABA

PHBA<smiles>O=C(O)c1ccc(C(=O)O)cc1</smiles><smiles>O=C(O)c1cc(C(=O)O)cc(N2C(=O)c3cccc4cccc(c34)C2=O)c1</smiles><smiles>O=C(O)c1ccc(N2C(=O)c3cccc4cccc(c34)C2=O)cc1</smiles>

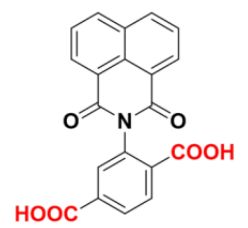

Figure S14. The doped guest molecules used in this paper.

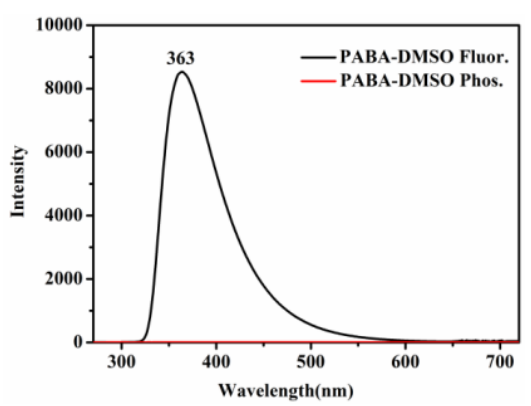

(a)

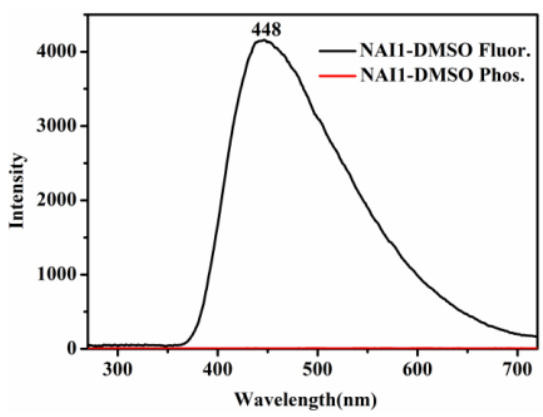

(c)

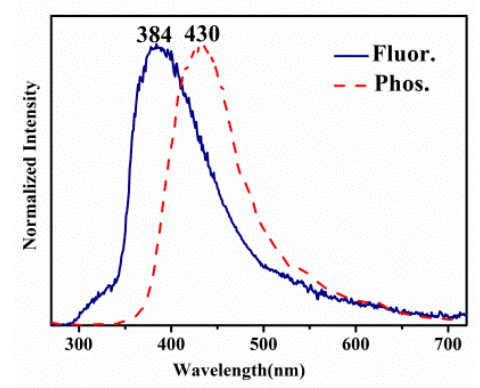

(b)

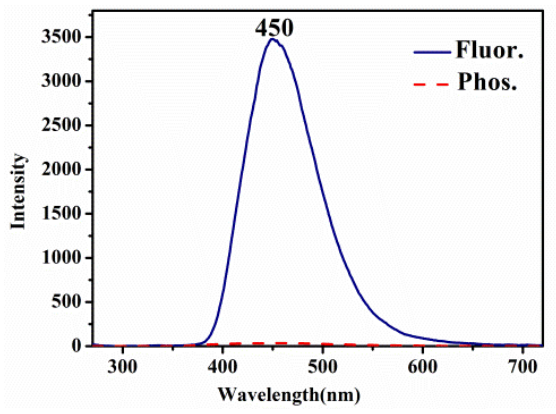

(d)

Figure S15. Luminescent spectra of DMSO solution (a) and solid (b) of PABA. Luminescent spectra of DMSO solution (c) and solid (d) of NAI1. Fluorescence spectra (solid line; excitation, $258 \mathrm{~nm}$; slit width, $5 \mathrm{~nm}$; voltage, $700 \mathrm{~V}$ ) and RTP spectra (dashed line; excitation, $258 \mathrm{~nm}$; slit width, $20 \mathrm{~nm}$; voltage, $700 \mathrm{~V}$ ). 


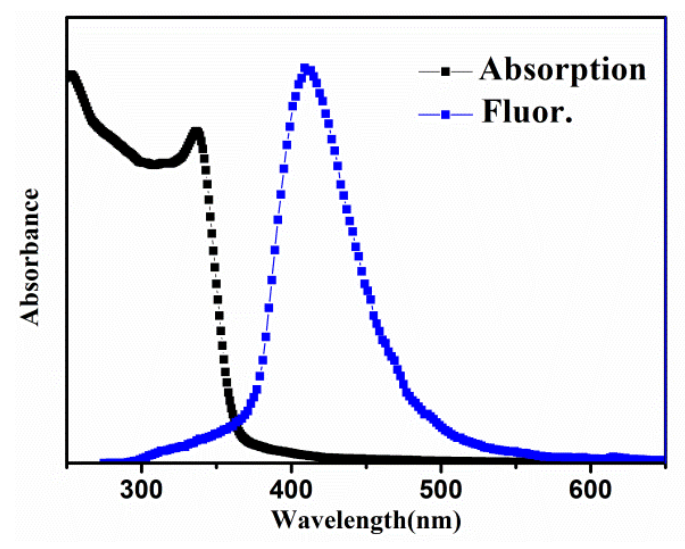

(a)

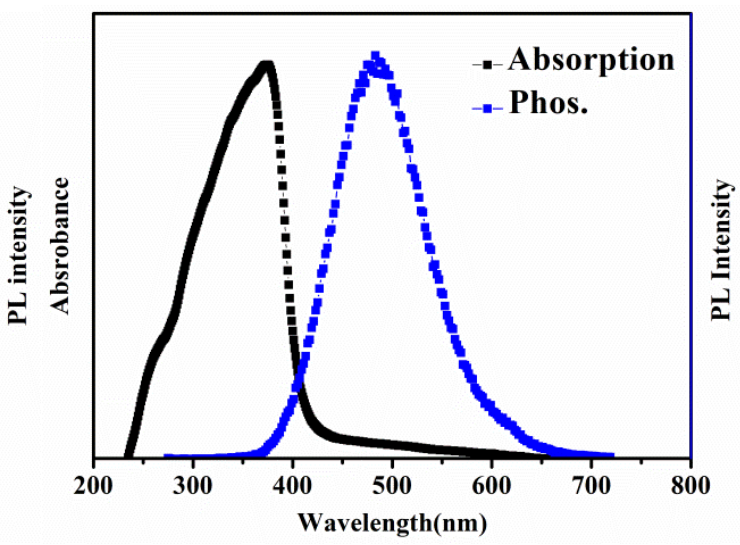

(b)

Figure S16. (a) The UV-vis absorption spectrum of PABA and the solid emission spectrum of $\mathbf{1}$. Excitation, $258 \mathrm{~nm}$; slit width, $2.5 \mathrm{~nm}$; voltage, $600 \mathrm{~V}$. (b) The UV-vis absorption spectrum of NAI1 and the solid emission spectrum of 1. Excitation, $258 \mathrm{~nm}$; slit width, $20 \mathrm{~nm}$; voltage, $600 \mathrm{~V}$.

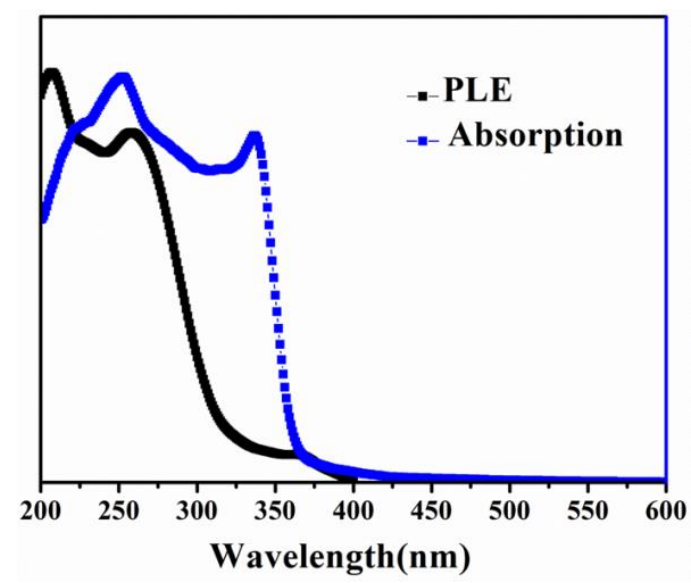

Figure S17. The UV-vis absorption spectrum of PABA and the solid excitation spectrum of $\mathbf{1}$.

Emission, $483 \mathrm{~nm}$; slit width, $20 \mathrm{~nm}$; voltage, $600 \mathrm{~V}$.

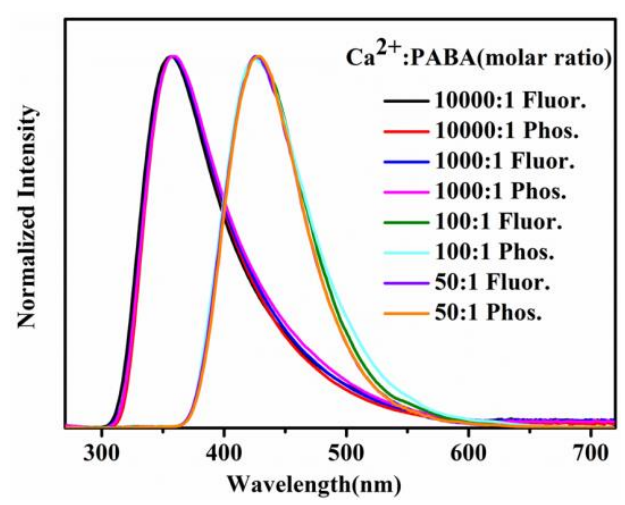

Figure S18. The solid emission spectra of PABA/1 with different PABA content. Fluorescence spectra (excitation, $258 \mathrm{~nm}$; slit width, $2.5 \mathrm{~nm}$; voltage, $700 \mathrm{~V}$ ) and RTP spectra (excitation, 258 $\mathrm{nm}$; slit width, $10 \mathrm{~nm}$; voltage, $700 \mathrm{~V})$. 


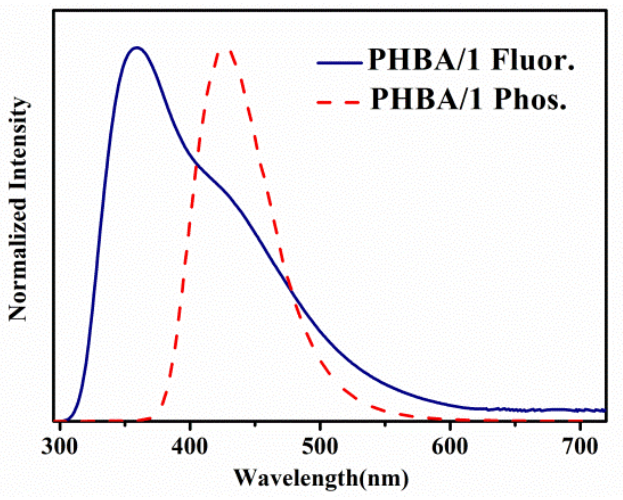

(a)

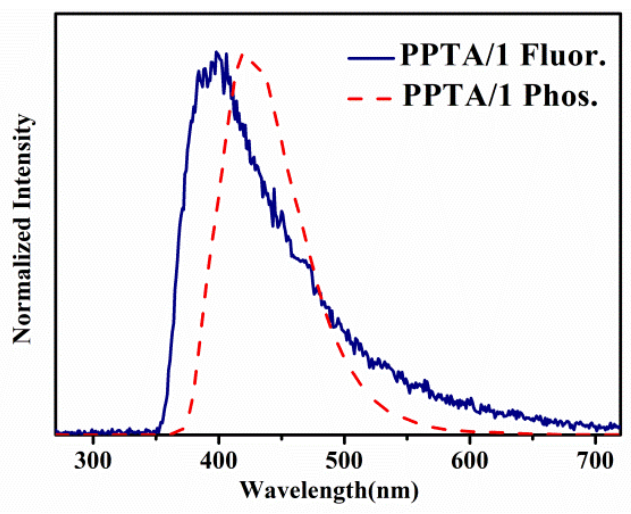

(c)

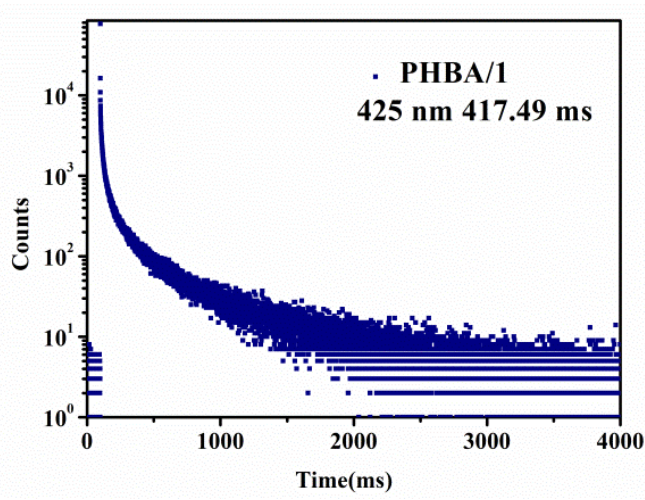

(b)

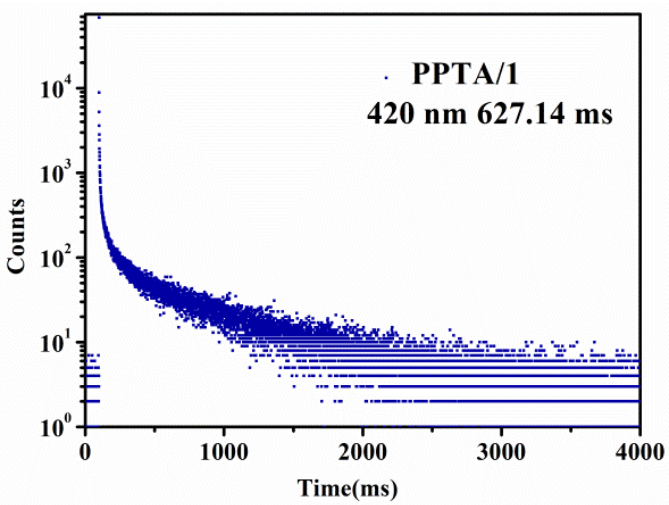

(d)

Figure S19. (a) Luminescence spectra of PHBA/1 under ambient conditions. Fluorescence spectra (blue solid line; excitation, $279 \mathrm{~nm}$; slit width, $2.5 \mathrm{~nm}$; voltage, $700 \mathrm{~V}$ ) and RTP spectra (red dashed line; excitation, $279 \mathrm{~nm}$; slit width, $10 \mathrm{~nm}$; voltage, $700 \mathrm{~V}$ ). (b) Time-resolved phosphorescence decay curve of $425 \mathrm{~nm}$ emission of PHBA/1. (c) Luminescence spectra of PTA/1 under ambient conditions. Fluorescence spectra (blue solid line; excitation, $254 \mathrm{~nm}$; slit width, 2.5 $\mathrm{nm}$; voltage, $700 \mathrm{~V}$ ) and RTP spectra (red dashed line; excitation, $254 \mathrm{~nm}$; slit width, $5 \mathrm{~nm}$; voltage, $700 \mathrm{~V}$ ). (d) Time-resolved phosphorescence decay curve of $420 \mathrm{~nm}$ emission of PTA/1.

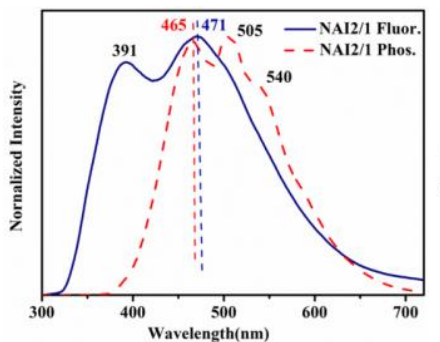

(a)

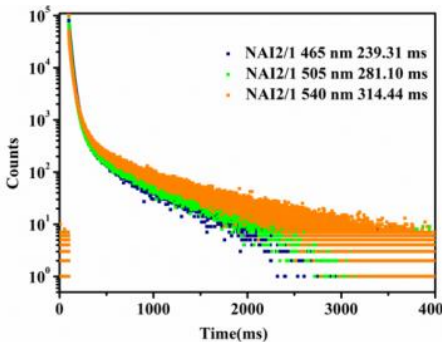

(b)

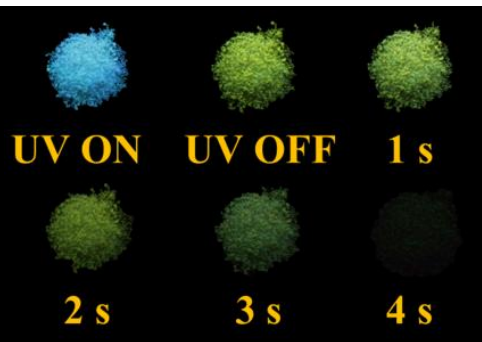

(c) 


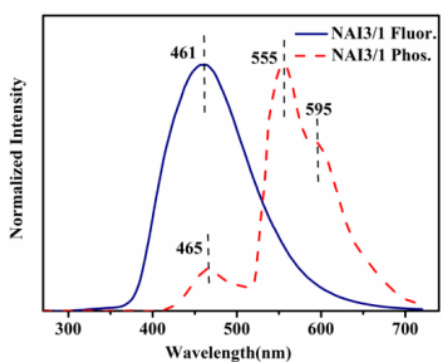

(d)

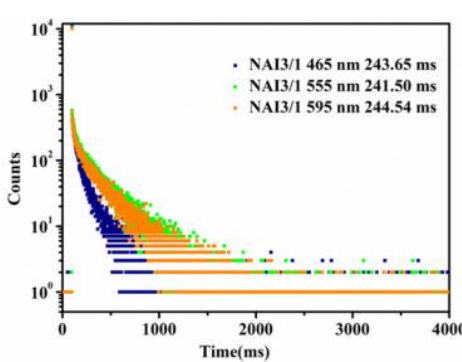

(e)

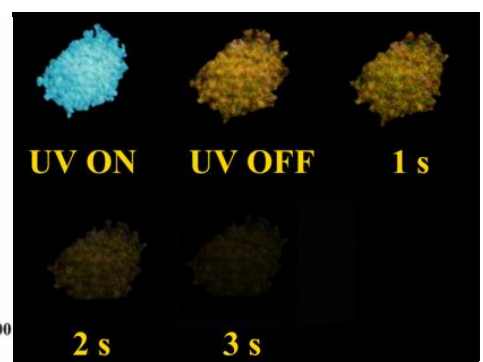

(f)

Figure S20. (a) Luminescence spectra of NAI2/1 under ambient conditions. Fluorescence spectra (blue solid line; excitation, $279 \mathrm{~nm}$; slit width, $2.5 \mathrm{~nm}$; voltage, $700 \mathrm{~V}$ ) and RTP spectra (red dashed line; excitation, $279 \mathrm{~nm}$; slit width, $10 \mathrm{~nm}$; voltage, $700 \mathrm{~V}$ ). (b) Time-resolved phosphorescence decay curves of 465, 505 and $540 \mathrm{~nm}$ emissions of NAI2/1. (c) Luminescence photographs of NAI2/1 under irradiation and upon removal of a UV lamp $\left(\lambda_{\mathrm{ex}}=254 \mathrm{~nm}\right)$. (d) Luminescence spectra of NAI3/1 under ambient conditions. Fluorescence spectra (blue solid line; excitation, $254 \mathrm{~nm}$; slit width, $5 \mathrm{~nm}$; voltage, $700 \mathrm{~V}$ ) and RTP spectra (red dashed line; excitation, $254 \mathrm{~nm}$; slit width, $20 \mathrm{~nm}$; voltage, $700 \mathrm{~V}$ ). (e) Time-resolved phosphorescence decay curves of 465, 555 and $595 \mathrm{~nm}$ emissions of NAI3/1.

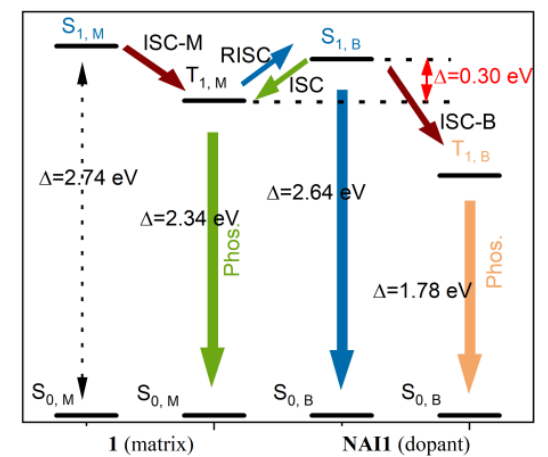

(a)

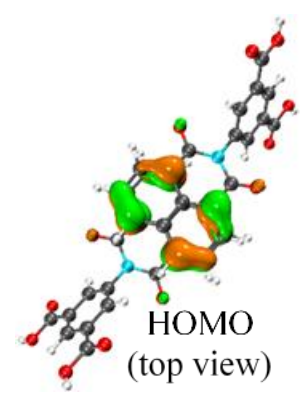

(d)

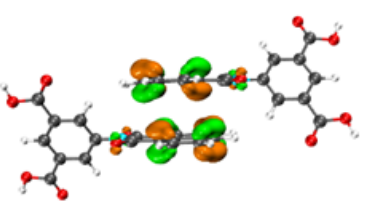

HOMO

(side view)

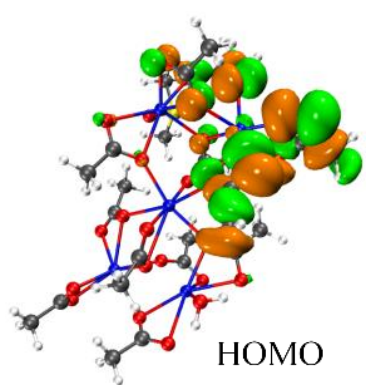

(b)

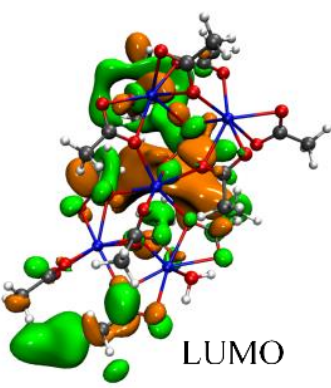

(c)

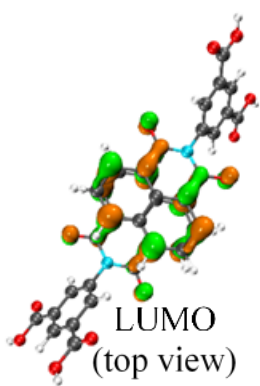

(f)

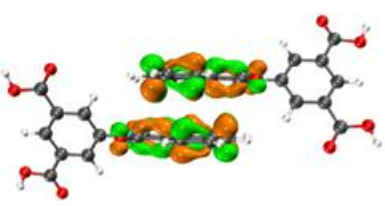

LUMO

(side view)

(g) 
Figure S21. (a) Jablonski diagram for 1 (matrix) and NAI1 (dopant), HOMO (b) and LUMO (c) electron density of the matrix, HOMO (d, e) and LUMO (f, g) electron density of the dopant along the top and side view, respectively. 